\begin{tabular}{|c|c|c|c|}
\hline Article Info & \multicolumn{2}{|c|}{ RESEARCH ARTICLE ARAŞTIRMA MAKALESİ } & \\
\hline Title of Article & \multicolumn{2}{|c|}{$\begin{array}{c}\text { Demographic Effects of Railway } \\
\text { Transportation and Infrastructure in } \\
\text { Turkey }\end{array}$} & \\
\hline $\begin{array}{l}\text { Corresponding } \\
\text { Author }\end{array}$ & \multicolumn{2}{|c|}{$\begin{array}{l}\text { Mehmet Aldonat BEYZATLAR } \\
\text { Dokuz Eylül Üniversitesi, İşletme Fakültesi, İktisat Bölümü, mehmet.beyzatlar@deu.edu.tr }\end{array}$} & \\
\hline $\begin{array}{l}\text { Received Date } \\
\text { Accepted Date }\end{array}$ & \multicolumn{2}{|l|}{$\begin{array}{l}26.07 .2021 \\
19.12 .2021\end{array}$} & \\
\hline DOI Number & \multicolumn{2}{|l|}{ https://doi.org/10.35674/kent.974815 } & \\
\hline Author / Authors & Mehmet Aldonat BEYZATLAR & ORCID: 0000-0002-8434-8447 & \\
\hline How to Cite & \multicolumn{2}{|c|}{$\begin{array}{l}\text { Beyzatlar, M.A. (2021). Türkiye'de Demiryolu Taşımacılığı ve Altyapısının } \\
\text { Demografik Etkileri, Kent Akademisi, Volume, 20, Issue 4, Pages, 1203-1218 }\end{array}$} & $\begin{array}{l}\text { Kent Akademisi } \\
\text { Urban Acaderny }\end{array}$ \\
\hline
\end{tabular}

\title{
Türkiye'de Demiryolu Taşımacılığı ve Altyapısının Demografik Etkileri
}

\begin{abstract}
:
This study aims to explore the demographic effects of railway transportation and infrastructure in Turkey. Variables used in this study comprise freight and passenger movement with railways as railway transportation, the length of the railway network as railway infrastructure, and population density and urbanization as the demographic measure. The dynamic connectedness approach is used as the methodology of this study to sort out the linkage between railways and demography in Turkey for the sample period between 1950 and 2019. This method is useful to obtain pairwise and combined directional parameters by providing a continuous conduction within all variables through the time dimension. Thus, a variant perspective to the determination of the interaction between railways and demography might bring an important contribution to the literature. According to the empirical results, all variables are found net transmitter except railway passenger transportation. Both demographic measures are found the strongest transmitters considering net and pairwise connectedness parameters. Therefore, urbanization and population density increase can be attributed to the coming of the railways, and vice versa, in a dynamic and transitive progress. It has been confirmed by an unconventional method that railways have an intense relationship with the demography in Turkey in the historical perspective.
\end{abstract}

KEYWORDS: Railway transportation, railway infrastructure, demography, connectedness, Turkey

\footnotetext{
${ }^{1}$ Dokuz Eylül University, Faculty of Business, Department of Economics, mehmet.beyzatlar@deu.edu.tr
} 
ÖZ:

Bu çalışma, Türkiye'de demiryolu taşımacılığı ve altyapısının demografik etkilerini araştırmayı amaçlamaktadır. Bu çalışmada kullanılan değişkenler, demiryolu taşımacılığı olarak demiryolları ile taşınan yolcu ve yük hareketliliği, demiryolu altyapısı olarak demiryolu ağının uzunluğu ve demografik ölçü olarak ise nüfus yoğunluğu ve kentleşmedir. Yöntem olarak dinamik bağlantılılık yaklaşımı, 1950 ile 2019 yılları arasındaki örneklem dönem için Türkiye'de demiryolları ve demografi arasındaki bağlantıyı ortaya çıkarmak için kullanılmıştır. Bu yöntem, önemli bir farklılık ve avantaj olarak da görülebilecek şekilde tüm değişkenler arasındaki etkileşimi zaman boyutunu da incelemek suretiyle zenginleştirerek ikili ve bütünleşik yönsel parametreleri elde etmek için kullanılmıştır. Bu nedenle, demiryolları ve demografi arasındaki etkileşimin belirlenmesine farklı bir bakış açısı kazandırılması literatüre önemli bir katkı sağlayabilir. Ampirik sonuçlara göre, demiryolu yolcu taşımacılığı dışındaki tüm değişkenlerin net aktarıcı olduğu bulunmuştur. Her iki demografik ölçümün (nüfus yoğunluğu ve kentleşme), net ve ikili bağlantılılık parametreleri dikkate alındığında en güçlü aktarıcı oldukları tespit edilmiştir. Kentleşme ve nüfus yoğunluğu artışı, karşılıklı olarak demiryollarının gelişimiyle dinamik ve geçişli bir süreç içerisinde etkileşim halindedir. Demiryollarının Türkiye'deki demografi ile tarihsel perspektifte yoğun bir ilişkisi olduğu konvansiyonel olmayan ve sürecin gerekliliklerine uygun bir yöntemle doğrulanmıştır.

ANAHTAR KELIMELER: Demiryolu taşımacılı̆̆ı, demiryolu altyapısı, demografi, bağlantılılık, Türkiye

\section{GíRiș:}

Genel anlamda ulaşım altyapısı ve bu altyapının kullanılmasıyla oluşan taşımacılık faaliyetleri, demografi üzerindeki etkileri bakımından bazı örneklerle açıklanabilir: (i) genişletilmiş ve/veya daha kapsamlı hale getirilen ulaşım, istihdam olanakları oluşturulmak suretiyle nüfusu (nüfus yoğunluğunu) artırabilir; (ii) daha iyi ulaşım, insanların daha düşük maliyetlerle ve daha yüksek yaşam kalitesiyle karşı karşıya kaldıkları alanlara taşınmasını sağlar; (iii) etkili ulaşım, insanların bu alanların yararları, avantajları ve firsatları için günlük veya mevsimsel olarak başka yerlere seyahat etme erişilebilirliğini arttırır. Özetle, mobilite ve ulaşım altyapısı, insanların ülke, şehir ve kırsal kesimlerdeki dağılımını, toplumu dönüştürmede ve nüfus değişimini etkilemede önemli bir işlev görmektedir.

Ulaşım altyapıları, sistemsel özelliklerine, yapılarına, türlerine, kalitelerine ve miktarlarına bağlı olarak ekonomik ve sosyal kalkınmayı doğrudan veya dolaylı olarak etkileyebilmesi mümkündür. Ulaşım altyapısındaki iyileştirmelerin maliyetleri düşürme, üretkenliği ve çıktıyı artırma, yeni pazarlara erişim, işsizliği azaltma ve ticareti destekleme gibi ekonomik faaliyetler üzerinde de faydaları vardır. Tarihsel olarak, ulaşım altyapılarındaki her gelişme hem peyzajın mekânsal organizasyonu hem de geniş çapta dağılmış nüfuslar arasındaki etkileşim açısından önemli sonuçlara sahiptir. Bu yorumlamalar 1şığında Lichter ve Fuguitt (1980) farklı dönemlerden çeşitli örneklere değinmişlerdir. On sekizinci yüzyılın sonlarında buhar motorunun icadı ve ulaşıma uygulanması, insanların ve malların hem su hem de kara yoluyla hareket etme şeklini derinden değiştirdi. On dokuzuncu yüzyılda, yeni geliştirilen teknolojiler daha fazla hız, taşıma kapasitesi ve güvenlik getirdi. Buharlı gemiler, ters rüzgarlarda tipik olarak bir haftalık bir yolculuğun üç ay sürebilme ihtimalini, yelkenle seyahat etmenin öngörülemezliğini ortadan kaldırdı. Yeni teknolojiler, teknik ve coğrafi avantajlardan ziyade, hem yeni gemilerin hizmet verdiği liman alanlarında hem de demiryollarının eriştiği bölgelerde yeni pazar firsatları anlamına geliyordu. Ancak bu yenilikler aynı zamanda üreticilerin, yetiştiricilerin ve şirketlerin dünya pazarında rekabet etmesi gerektiği anlamına geliyordu. Buhar teknolojisinin ortaya çıkışı, ülke ekonomilerinde yabancı katılımın artması anlamına geliyordu. Hammaddeye taşeronlara ve pazara kolay erişim (olası müşteriler), yabancı girişimcileri diğer ülkelerde yatırım yapmaya ve pazarı yerel üreticilerle paylaşmaya teşvik etti. Demiryollarının genişlemesi, Amerika Birleşik Devletleri, Büyük Britanya ve Rusya'da demir ve çelik üretimi gibi ağır sanayilerin büyümesini destekledi. Demiryolları geniş iç alanları fethetti, nakliye maliyetlerini keskin bir şekilde düşürdü ve iç bölgeler (hammaddeler) ile kıyıya (limanlar, havaalanları vb.) bağlı alanlar gibi ilgili alanlar arasında önemli bağlantılar kurdu.

$\mathrm{Bu}$ nedenle ulaşım altyapısına yapılan yatırımlar, ulaşım maliyetlerini düşürerek, taşımacılık faaliyetlerini yoğunlaştırarak ve ticareti kolaylaştırarak doğrudan ekonomik kalkınmaya önemli katkılar sağlamaktadır. Ulaşım altyapısı tarafından sağlanan hizmetler, artan mal ve hizmet hareketliliği nedeniyle ekonomik faaliyetler için esastır. 
Daha düşük maliyetler ve pazarlara erişim kolaylığı hem kamu hem de özel sektör açısından sektörel, mekânsal ve bölgesel gelişmeye neden olmaktadır (Aschauer, 1989; Munnell, 1990; Gramlich, 1994; Bougheas vd., 2000). Ulaşımdaki gelişmeler, artan erişilebilirlik, uzmanlaşma ve pazar genişlemesine neden olarak, ölçek getirilerinin artmasına ve mekânsal yığılma etkilerinin yanı sıra inovasyonların yayılımına da imkan sağlamaktadır. Sonuç olarak, toplam faktör verimliliği ve ekonomik büyüme artar (Bougheas vd., 2000; Lakshmanan, 2007). Ulaşım altyapısının ekonomik kalkınmaya etkilerinin, gelişmiş ülkelerden ziyade gelişmekte olan ülkelerde daha yorumlanabilir olduğu öne sürülmüştür (Zhou vd., 2007).

Bu çalışmanın amacı, 1950-2019 dönemi için Türkiye'deki demiryolu taşımacıllı̆ğ ve altyapısının demografik etkilerini dinamik bağlantılılık yöntemi ile incelemektir. Bu çerçevede, demiryolu taşımacıllı̆ı ile ulaşım faaliyetleri temsil edilirken, demiryolu ile taşınan yolcu ve yük verileri ile çalışılmıştır. Demiryolu altyapısı ile de ulaşım altyapısı simgelenirken, demiryolu hat uzunluğu verilerinden yararlanılmıştır. Diğer taraftan demografik etkileri temsilen nüfus yoğunluğu ve kentleşme verileri kullanılmıştır. Çalışmada kullanılan dinamik bağlantılılık yöntemi sayesinde elde edilecek analiz sonuçları farklı yönler içeren entegre bir değerlendirmeye imkan sağlamaktadır. İlk olarak belirtilmesi gereken husus, yöntem dahilinde kullanılan değişkenler arasında bağımlı bağımsız ayrımı yapmaksızın, örneklem dönemi kapsamında değişkenler arası etkileşim parametrelerini sağlamak mümkündür. $\mathrm{Bu}$ parametreler sadece değişkenler arası karşılıklı ilişkileri değil aynı zamanda sistemdeki herhangi bir değişkenin geriye kalan diğer tüm değiş̧enler ile de toplu ve karşılıklı etkilerine ulaşabilmek mümkündür. Böylece değişkenlerin sistem içerisindeki yerini netleştirebilmek ve değişkenler üzerine yapılabilecek yorumlamaları zenginleştirebilmek mümkündür. $\mathrm{Bu}$ parametrelerin örneklem döneminin tümü için türetilebilmesi de ayrıca önemli bir katkı olarak değerlendirilmiştir. Böylece, dinamik bir etkileşim süreci elde etmek ve sürecin nasıl ilerlediğini görmek mümkündür. Sonuç olarak, bu yöntem sayesinde, politika yapıcılar için demiryolu taşımacılığı ve altyapısı özelinde daha sağlam ve süreç odaklı ampirik destek sağlanması amaçlanmaktadır.

Bu çalışma, "Giriş" ve "Sonuç" kısımlarının yanı sıra dört bölüm daha içermektedir. Birinci bölüm, Türkiye'deki demiryollarının kısa bir tarihini aktarmaktadır. İkinci bölümde literatür taraması verilmektedir. Üçüncü bölüm, verileri ve çalışmada kullanılan ampirik yöntemi içermektedir. Dördüncü bölüm ise ampirik bulguları ortaya koymaktadır.

\section{Türkiye'de Demiryollarının Tarihsel Gelişimi}

Anadolu topraklarında yer alan demiryolları, yüz elli yılı aşkın bir geçmişe sahip olmasının yanı sıra, sadece bir ulaşım sistemi değil, aynı zamanda ülkenin kaderinin şekillenmesinde önemli rol oynayan en önemli kurumlardan biri olmuştur. 1856 yılında yaklaşık 130 kilometrelik İzmir-Aydın demiryolu hattının inşa edilmesiyle başlayan demiryolu serüveni, bir bakıma bu toprakların 150 yılı aşkın geçmişinin de aynası olarak görülebilir.

1856 ve sonrasında inşa edilen demiryolu hatları ve güzergahları, ekonomik ve siyasi hedeflere göre şekillendirilmiştir (Talbot, 1981). Demiryolu inşaatı son derece pahalı bir yatırım olmasına rağmen, başta ekonomik, siyasi ve askeri alanlar olmak üzere birçok düzeyde avantaj sağlamıştır. Bu avantajlar hem kamu hem de halk açısından önemliydi. Demiryollarının yapımına Anadolu'nun batısından başlanmış, ancak daha sonra demiryolu ağının Anadolu'nun iç kesimlerine doğru yayılması devam etmiştir. Demiryolu altyapısının gelişimiyle oluşan bağlantılar önemli, hayati ve stratejikti. Sadece kamu idari gerekçeleri bağlamında değil, aynı zamanda askeri ve ekonomik hususlar bakımından da önemliydi (Abdülhamid, 1999). Asker ve mühimmatın sınır bölgelerine ve kritik alanlara sevkiyatı kolaylaşmıştı. Ekonomik olarak, taşıma maliyetlerinin azalmasıyla birlikte demiryolları ile eşya, hayvan ve yolcu taşımacılığı daha uygun hale geldi. Yirminci yüzyılın ilk on yılına gelindiğinde, tüm demiryolu hatlarından mal ve yolcu taşınmaya başlandı. Hammaddeler, yarı mamuller, mamuller, madenler ve tarım ürünleri daha büyük miktarlarda daha iyi koşullarda taşınmıştır (Earle, 1966).

Demiryollarının ekonomik kalkınma üzerindeki olumlu etkileri yolcu taşımacıllğı tarafında da görülmektedir. Yolcu hareketliliğinin artmasıyla birlikte, uzak şehirler daha erişilebilir hale geldi. Toplum ve demiryolları arasındaki etkileşim sonucu olarak banliyöleşme meydana geldi. Ayrıca, demiryolu bölgelerinin nüfusu diğer bölgelere göre orantılı olarak daha hızlı büyüdüğü görülmüştür (Faroqui vd., 1997). 
Yolcu ve yük taşımacıllı̆ı sadece demiryolu ağının gelişmesinden etkilenmemiş, diğer sektörler de demiryollarının yayılmasından etkilenmiş̧ir. Bu kapsamda tarım, demiryolu ağı gelişiminin etkisi altına girmiştir (Faroqui vd., 1997). Ticaret hacmi yüksek ve yoğun nüfuslu şehirlerin çevresinde demiryolu ağı inşasına hız verilmiştir.

Türkiye'nin modern tarihi ve Türkiye'de demiryollarının altın çağı, Cumhuriyetin kurulmasıyla başladı. Demiryollarının ekonomik ve güvenlik etkilerinin yanı sıra sosyal etkileri de önemliydi (Eldem, 1970). Demiryolları, silahlardan, cephaneliklerden ve diğer birçok silahtan daha önemli bir güvenlik sorunuydu. Demiryolları zengin ve medeni bir ülke olmanın gerekli unsurları arasındaydı. Bu kapsamda, ülkenin genel kalkınma hedeflerinin ana bileşenlerinden birinin ulaşım altyapısı, özellikle de demiryolları olduğu görülmekteydi. Bu amaçlarla, Türkiye Cumhuriyeti Devlet Demiryolları (TCDD) Türkiye Cumhuriyeti sınırları içinde kalan mevcut demiryollarının işletmesini devralmak üzere 1927 yılında kurulmuştur. Teşkilatın işlevi, demiryollarını sadece işletmek değil, aynı zamanda ülkenin ihtiyaçlarına göre geliştirmekti.

Cumhuriyetin ilk yıllarından itibaren demiryollarına olan ilgi giderek artmakta ancak demiryollarının yapım süreci, İkinci Dünya Savaşı'na kadar giderek daha da zorlu bir ekonomik durum içerisinde ilerlemiş̧ir (Faroqui vd., 1997). 1923-1950 yılları arasındaki dönemde, yani 27 yılda yaklaşık $7700 \mathrm{~km}$ demiryolu inşa edildi, ancak bu miktarın yaklaşık 7000 km'si 1940'tan önce tamamlandı. Demiryolu inşaatı açısından 1940-1950 dönemi, bir gerilemeden ziyade konjonktüre paralel olarak yavaşlamadan kaynaklanıyordu. Tüm zorluklara rağmen demiryolu hatları üretim merkezleri ile doğrudan bağlantıları sağlama amaçları doğrultusunda genişletilmeye devam etmiştir.

Karayolları, 1950 yılına kadar uygulanan ulaştırma politikaları kapsamında demiryollarını destekleyen ve sadece entegre edilen bir sistem olarak görülüyordu. Ancak 1950'lerden sonra senaryo değişti ve öncelikler demiryolu inşaatından karayolu inşaatına kaydıııldı. Karayolu inşaatlarına hız verilmesinde Marshall Yardımlarının etkisi büyüktü. Ulaştırma politikalarında demiryolları görmezden gelindi. Karayolları ve otoyollar, yolcu ve yük taşımacılığında ilk tercih haline geldi. Trenlerin yerini otobüs ve kamyonlar aldı. Ayrıca, hammaddelerin yurt içinde ve yurt dışında sanayi merkezlerinden tüketici pazarlarına ulaşım kolaylıklarının sağlanmasındaki önemi nedeniyle haberleşmeye yüksek öncelik verildi. İktisat politikaları, doğal kaynakların rasyonel kullanımı, tarımın yoğunlaştırılması ve iyileştirilmesi, güç kaynaklarının rasyonel bir temelde kullanılması ve iletişim araçlarının geliştirilmesini amaçlamıştır (Üstün, 1997).

Bu ulaşım politikalarının bir sonucu olarak, karayolu taşımacıllı̆ı̆ Türkiye'nin ana ulaşım sistemi haline geldi. Her ne kadar demiryollarına verilen önemin gerilediği yönünde bir süreç olsa da demiryolu taşımacılığı ve altyapısı artan bir trend içermektedir. İnşa edilen demiryolu hat uzunluğu incelendiğinde rakamların yatay devam ettiği dönemler olsa da bu dönemleri demiryollarının geliştirilmesi ve toplumun önceliklerine göre şekillendirilmesi olarak değerlendirmek gerekir. Zira karayolları ile demiryolları karşılaştııılması altyapı açısından pek mantıklı değildir. Demiryolu ağının karayolları kadar esnek kullanım olanaklarına sahip olmaması doğal bir biçimde karayollarına odaklanılmasına neden olmuştur.
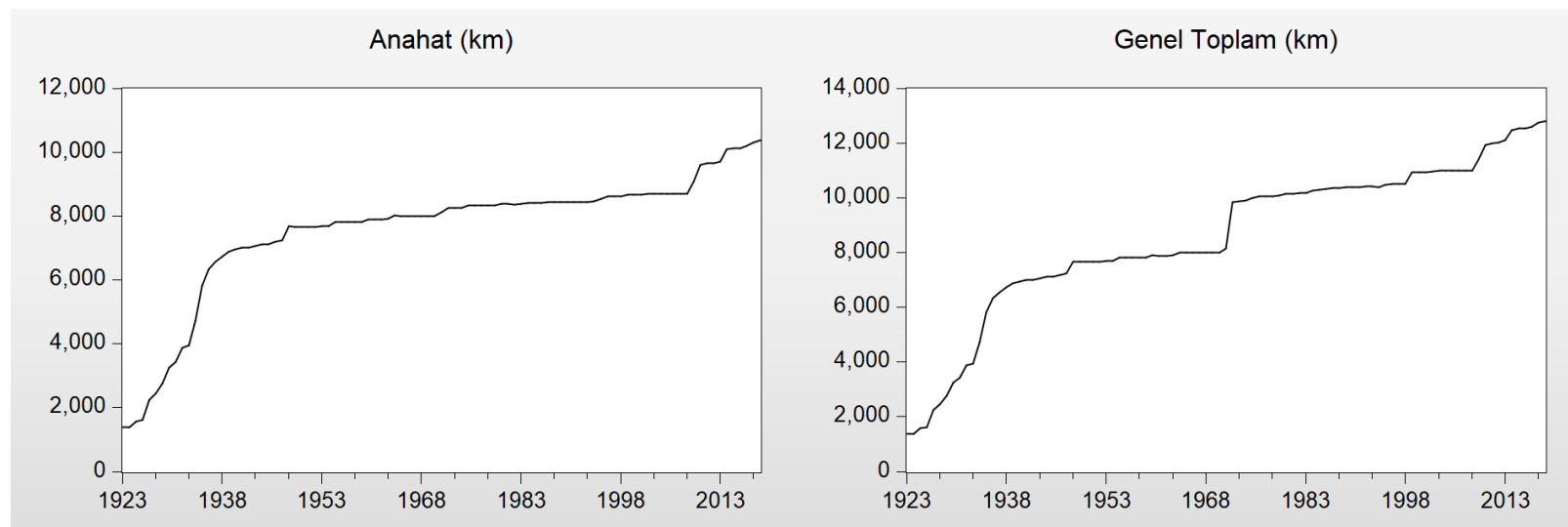

Şekil 1. Demiryolu Hat Uzunluğu (1923-2019) (veri kaynağı Url 1) 
Demiryolu altyapısı ile ilgili rakamları içeren Şekil 1 incelendiğinde, inşa edilen demiryolu anahat uzunluğu 19231950 dönemi ortalama y1llık $225 \mathrm{~km}$ iken, bu rakam 1950-2000 döneminde ortalama $20 \mathrm{~km}, 2000-2019$ döneminde ise $85 \mathrm{~km}$ düzeyindedir. 1923-2019 dönemi ortalaması ise $93 \mathrm{~km}$ seviyelerindedir. Genel toplam hat uzunluğuna bakıldığında ise 1923-1950 dönemi $225 \mathrm{~km}, 1950-2000$ dönemi 64 km, 2000-2019 dönemi 94 km ve son olarak 19232019 dönemi ise $118 \mathrm{~km}$ olarak inşa edilmiştir.
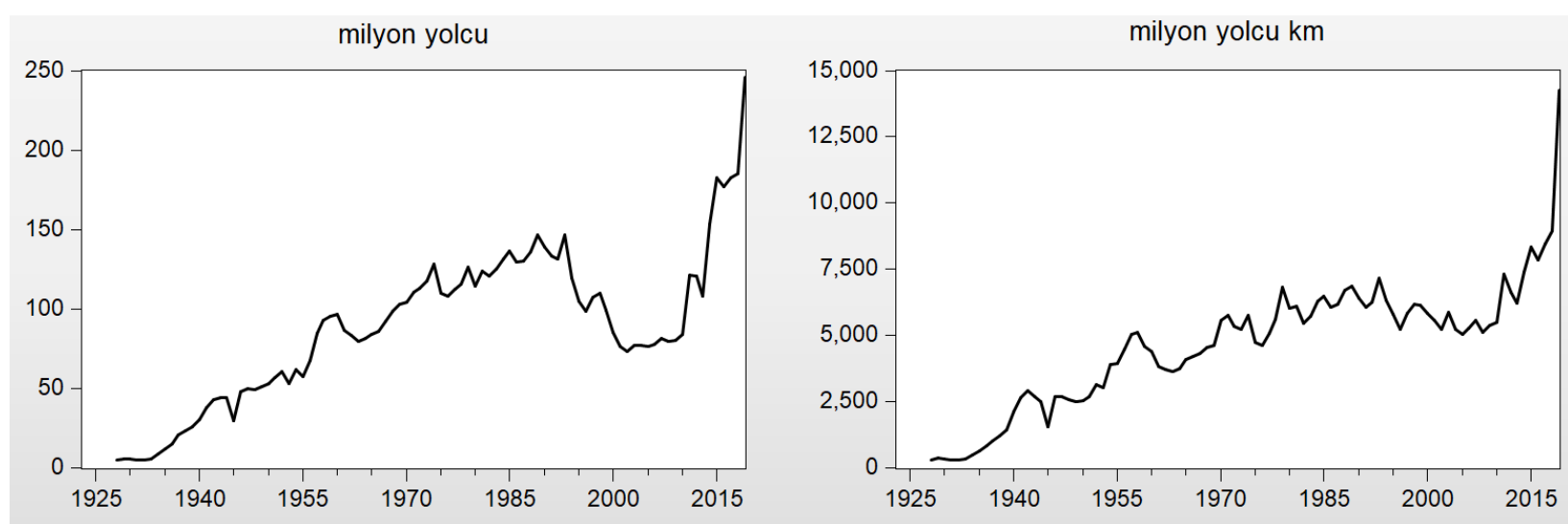

Şekil 2. Demiryolu Yolcu Taşımacılı̆̆g (1928-2019) (veri kaynağı Url 1)

Demiryolu yolcu taşımacıllğı rakamlarını içeren Şekil 2 incelendiğinde, 1928-2019 dönemi yıllık ortalama 88 milyon yolcu ve 4609 milyon yolcu km olarak karşımıza çıkmaktadır. Demiryolu yolcu taşımacılığı rakamları dönemler şeklinde incelendiğinde 1928-1950 yılları arasında yıllık ortalama 27 milyon yolcu ve 1506 milyon yolcu km olarak gerçekleşirken, 1950-1980 döneminde bu rakamlar yıllık ortalama 93 milyon yolcu ve 4577 milyon yolcu km seviyelerine yükselmiştir. 1980-2000 döneminde artış devam etmiş, yıllık ortalama 123 milyon yolcu ve 6151 milyon yolcu km düzeyine çıkmıştır. 2000-2019 döneminde ise yıllık ortalama 119 milyon km ve 6793 milyon yolcu km ile demiryolu yolcu taşımacılığı rakamları ortaya çıkmıştır. Genel olarak değerlendirildiğinde son dönem hariç demiryolu yolcu taşımacıllğı yıllık ortalama değer artı̧̧ı devam ederken, taşınan yolcuların kaç km taşındıklarını veren istatistiklerin sürekli artış gösterdiği görülmektedir.

Demiryolu yük taşımacılığı ile ilgili olarak Şekil 3 incelendiğinde, 1928-2019 örneklem döneminde yıllık ortalama 14 milyon ton ve 6138 milyon ton km rakamları görülmektedir. 1928-1950 yılları arasındaki ilk döneme bakıldığında yillık ortalama 5 milyon ton ve 1539 milyon ton km, 1950-1980 döneminde yıllık ortalama 14 milyon ton ve 5471 milyon ton km, 1980-2000 arasında yıllık ortalama 15 milyon ton ve 8019 milyon ton km, son olarak ise 2000-2019 döneminde ise yıllık ortalama 23 milyon ton ve 10778 milyon ton km yük taşımacılığı demiryolları vasıtasıyla yapılmıştır. Genel olarak demiryolu yük taşımacılığı rakamlarında her dönem artış gözlemlenmiş, ancak en büyük artış 2000 sonrası dönemde gözlemlenmiştir.
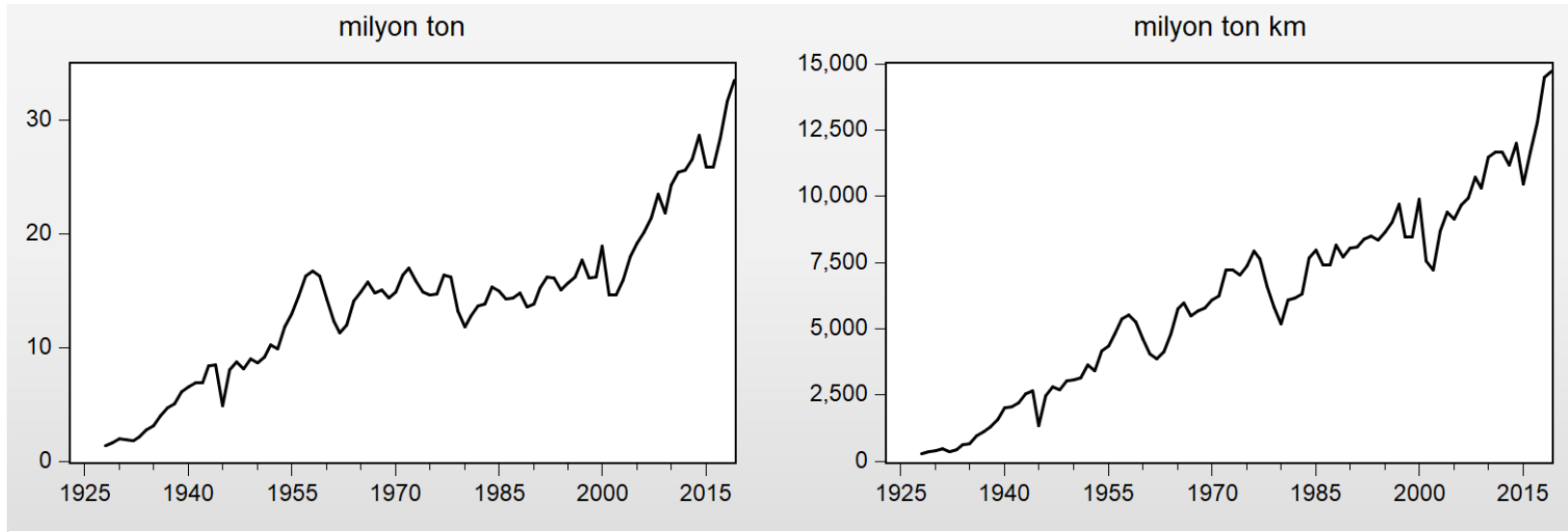
Şekil 3. Demiryolu Yük Taşımacılığı (1928-2019) (veri kaynağı Url 1)

Şekil 1,2 ve 3 birlikte incelendiğinde demiryolu taşımacıllğında yaşanan artışların demiryolu altyapısına yani demiryolu hat uzunluğuna rağmen daha yüksek olduğu dikkati çekmektedir. Artan bu yoğunluğun gereksinimlerini karşılayabilmek için sadece yeni demiryolu inşasının zorunluluk olmadığı, yolların iyileştirilmesi ve istasyonların etkinliklerine göre değerlendirilmesi söz konusudur. Demiryolu taşımacılığını geliştirmek ve artırmak için kamu (eski adıyla Ulaştırma, Denizcilik ve Haberleşme Bakanlığı yeni adıyla Ulaştırma ve Altyapı Bakanlığı) girişimleri ve teşvikleri bağlamında, yurt içinde ve yurt dışında dengeli, güvenli, çevre dostu, adil, uygulanabilir ve ucuz koşullarda yolcu ve yük taşınmasının sağlanması amaçlanmaktadır. Türkiye demiryolu ağının son durumu Şekil 4'te görülebilmektedir. Harita incelendiğinde toplumun ihtiyaçlarının yansıra, coğrafi şartların ne kadar önemli bir etken olduğu görülmektedir.

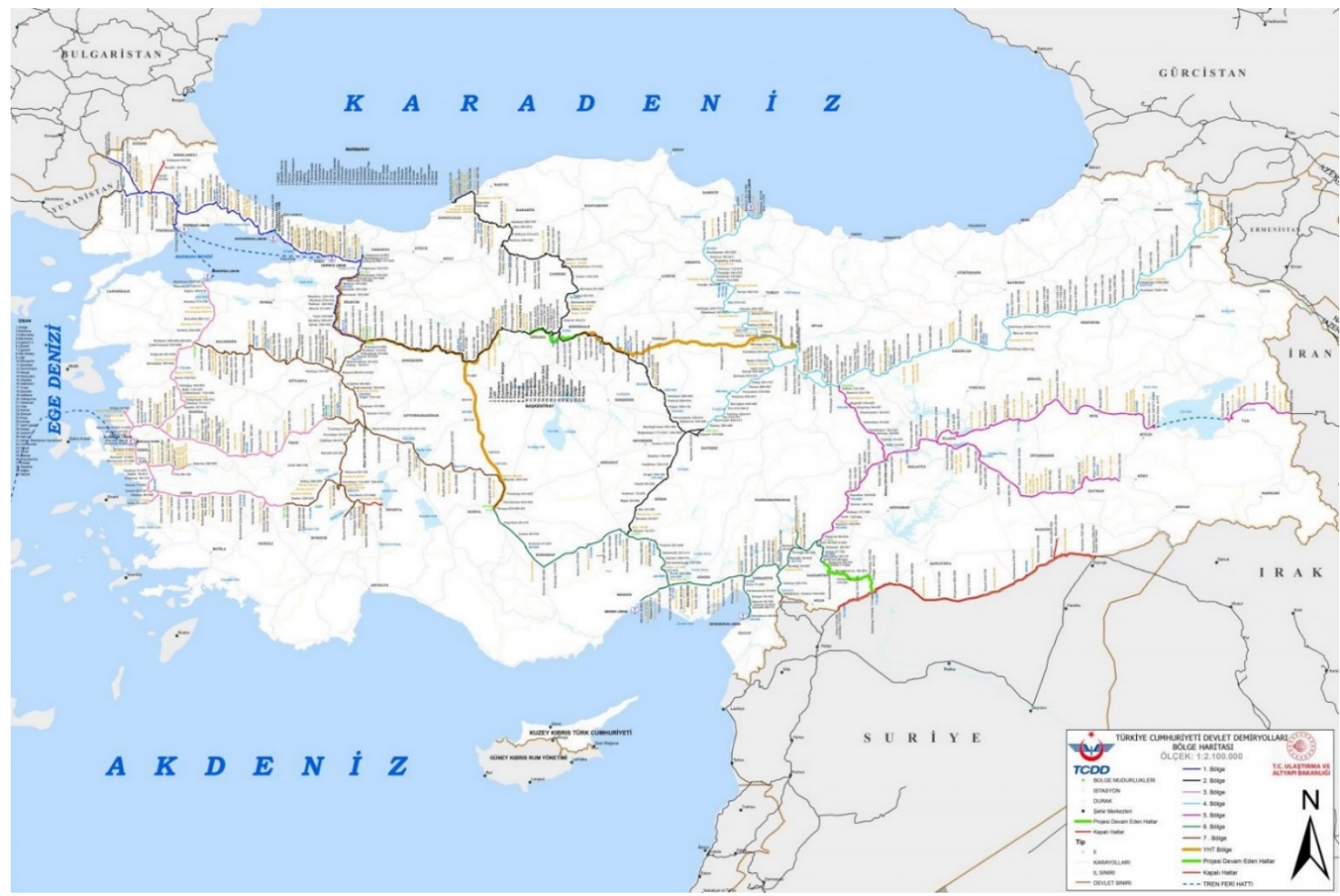

Şekil 4. TCDD Bölge Haritası (Url 2)

\section{Literatür Taraması}

Ulaşım ve ulaşım altyapısının nüfus dağılımı, göç ve kentleşme gibi nüfusun değişimine dayalı değiş̧kenler üzerindeki etkileri literatürde çok yönlü olarak araştırılmıştır (William, 1958; Kanwit ve Todd, 1961; Thiel, 1962; Taaffe vd., 1963; Gamble vd., 1966; Hobbs ve Campbell, 1967; Bohm ve Patterson, 1971; Wisenbaker, 1973; Fuguitt ve Beale, 1976). Bu çalışmaların tamamında ulaşım ve ulaşım altyapısı ile nüfus değişkenleri arasında pozitif bir etkileşim bulunmuştur. Temelde ulaşım ve nüfus ölçümlerini ele alan bu çalışmalarda ayrıca fiziksel çevre, demiryolu rekabeti, ara konum ve ticarileştirme gibi ek faktörlerin de incelendiği gözlemlenmiştir. Ulaşım ağlarının genişletilmesi yoluyla iç erişilebilirliğin iyileştirilmesi, azgelişmiş ülkelerin ekonomik büyümesinde kritik bir faktör olarak gözlemlenmiştir. Bu bağlamda ulaşım ağları ile nüfus arasındaki etkileşim şu şekilde değerlendirilmiştir; bir bölgede nüfus arttığında ulaşım talebi yoğunlaşıyor, bölgeye yeni ulaşım hatları inşa ediliyor, daha büyük bir nüfus artışı teşvik ediliyor ve bu da daha fazla ulaşım gerektiriyor (Taaffe vd., 1963). 
Ulaşım ve demografi arasındaki ilişkileri inceleyen ve pozitif bir ilişki ortaya koyan bazı çalışmalar için sadece karayollarına eğilimin yeterli olmadığı farklı yatırım olanaklarına yönelim ve ulaşımda çeşitliliğe gidilmesinin önemli olduğu belirtilmiştir (Humphrey, 1980; Briggs, 1981; Eyerly vd., 1987; Moon, 1988; Crane ve Leatham, 1990; Doeksen, 1990; Fuguitt ve Brown, 1990; Gerardin, 1991; Boarnet ve Haughwout, 2000). Bu çalışmalarda yeni ulaşım sistemlerinin inşa edilmesi, ulaşım altyapısına yapılan yatırımlar, ulaşım odaklı kamu sermaye yatırımları ve kamu harcamaları ile nüfus değişimleri üzerinde istatistiksel olarak anlamlı etkiler bulmuştur. Ayrıca ulaşım altyapı yatırımlarının kentsel alanların büyümesini şekillendirmede ve nüfusu kentlere kanalize etmede önemli bir faktör olduğu görülmüsstür. Mikro bazda ise ulaşımın iyileşmesinin arazi fiyatlarını, nüfusu ve istihdam ölçümlerini etkilediği belirtilmiştir.

Ulaşım hareketliliğinin gelirle orantılı olarak arttığı, hanehalklarının gelirlerinin belirli bir kısmını mutlaka ulaşım ve seyahat etmek için ayırdı̆̆ı yönünde sonuçlara ulaşan çalışmalar mevcuttur (Schafer ve Victor, 2000; Cervero ve Hansen, 2002; Voss ve Chi, 2006; Chi vd., 2006; Chi, 2010). Bu çalışmaların sonuçlarına göre özetle, gelirdeki bir artış, doğrudan hareketlilik talebinde bir artışa yol açmaktadır. Sonuçlar, ulaşım altyapısının belirli kentleşme kalıplarını, nüfus yoğunluğunu, arazi kullanımını ve ulaşım altyapısından etkilenen seyahat davranışını barındıracak şekilde inşa edildiğini göstermiştir.

Ulaşım altyapı ağının genişletilmesi ve nüfus yapısı üzerindeki etkilerini inceleyen bazı çalışmalara göre ulaşım altyapısı inşaatının şehirlerin merkezileşmesinde, banliyö ve kırsal kesim nüfus yapısının değişmesinde ve şehirlerin istihdam ve konut yapılarının etkilenmesinde çok önemli bir rol oynadığını belirtmişstir (Wang, 1987; Cervero ve Hansen, 2002; Snow, 2010). Böylece yeni kentsel ulaşım altyapısı oluşturulması, nakliye maliyetlerini düşürerek ve verimliliği artırarak firmalara avantajlar sağlayacaktır. Bir diğer açıdan hanehalklarının daha yüksek ücretlere ve daha düşük konut maliyetlerine ulaşabilirliği de sağlanabilmiş olacaktır. Sonuç olarak, yeni ulaşım olanaklarını sağlayacak yatırımlar ile firma ve emek verimliliğinin yaygınlaşabilmesi ve uzak mesafelerden dahi aynı verimlilik avantajlarına ulaşılabilir hale gelmesi sağlanabilecektir.

Nüfusun ve nüfusun ekonomiye entegre olmasıyla ortaya çıkan istihdamın ulaşım altyapısından olumlu etkilendiğini tespit eden birçok çalışma yer almaktadır (Allen ve MaClennan, 1970; Zahavi, 1976; Gaegler vd., 1979; Hilewick vd., 1980; Lichter ve Fuguitt, 1980; Carlino ve Mills, 1987; McHugh ve Wilkinson, 1988). Bu çalışmalarda, nüfusun ve istihdamın mekânsal dağılımının, seyahat davranışı ve ulaşım altyapı sistemleriyle bağlantılı olduğu tespit edilmiştir. Gelişmiş ulaşım altyapısına sahip olan yerleşim yerlerinin, nüfus artışı, vasıflı göç ve istihdam artışında diğer bölgelere göre sürekli olarak bir avantaj sağladığı ortaya koyulmuştur. Özellikle imalat sektöründe yaşanan artışla birlikte perakende sektörü satışlarının ve arazi değerlerinin artması, nüfus ve ekonomik faaliyetlerin düzeyi ve dağılımının olumlu etkilenmesi, ulaşım altyapısının modernizasyonunun sağladığ olduğu belirtilmiştir. Bu çalışmalarda, ulaşım yatırımlarının nüfus, istihdam, gelir, gayri safi bölgesel hasıla ve genel ekonomik yapı gibi demografik ve ekonomik ölçütler üzerinde kısa, orta ve uzun vadeli sonuçları olduğu kanısı hakimdir. Özellikle bazı araştırmalarda toplam istihdam, imalat istihdamı ve nüfus yoğunluğu değişkenlerinin ulaşım altyapısı yoğunluğundan olumlu etkilendiğini bulmuştur (Carlino ve Mills, 1987; McHugh ve Wilkinson, 1988).

Literatürdeki çalışmalarda varılan genel kanı ulaşım altyapısının en dar kapsamda yerel ekonomik büyüme ve kalkınma için yeterli bir gereklilik, nüfus artışında etken ve değişimin katalizörü olarak görüldüğüdür. Ulaşım altyapısı nüfus, nüfus değişimi, nüfus yoğunluğu, kentleşme ve göç gibi demografik ölçüleri etkileyen ve/veya bunlardan etkilenen önemli faktörlerden biri olarak görülmektedir (Taaffe vd., 1963; Lichter ve Fuguitt, 1980; Atack vd., 2009; Chi, 2010; Snow, 2010).

Ulaşım altyapısı olarak, kişisel otomobil kullanımı, otobüs, uçak ve tren yolculuğu ile ilgili farklı veriler, ulaşım ağları ve su yolları gibi farklı değişkenlerin kullanılmasıyla daha kapsamlı çalışmalar ortaya çıkmıştır (Schafer ve Victor, 2000; Robinson ve Kapo, 2004; Levinson, 2008; Atack vd., 2009). Schafer ve Victor (2000), çeşitli ulaşım ölçümlerinin nüfus yoğunluğu üzerindeki etkilerini incelemiş̧ir ve pozitif ilişkili olduklarını ortaya koymuştur. Robinson ve Kapo (2004) ise ulaşım ağları ve nüfus yoğunluğu dağılımı arasındaki etkileşimi araştırdı ve nüfusun yoğun olduğu merkezlerde altyapı için gerekli geliştirme, bakım ve onarım faaliyetleri ile doğrudan ve dolaylı olarak yüksek pazar talebi oluşturduğunu ortaya koymuştur. Levinson (2008) demiryolu ağında ve nüfus yoğunluğunda meydana gelen değişiklikleri incelerken demiryollarının merkezileştirici mi yoksa merkezi olmayan bir güç mü olduğu sorusuna odaklanmıştır. Sonuç olarak da demiryolu ağ yoğunluğunun nüfus yoğunluğunu etkileyen olumlu bir 
faktör olduğunu belirtmiş̧ir. Atack vd. (2009) ulaşım altyapısının nüfus yoğunluğu ve kentleşme üzerindeki etkilerini incelemiştir. Elde edilen sonuçlara göre demiryollarının nüfus yoğunluğu artışı üzerindeki etkilerinden ziyade nüfus yoğunluğunda yaşanan artışların demiryolu altyapısına olan ihtiyacı tetiklediğinin ön plana çıktığını belirtmiştir.

Ulaşım ve ulaşım altyapısının demografik etkileri üç önemli nokta ile özetlenebilir. Birincisi, genişletilmiş ulaşım altyapısı ve olanakları, çevredeki alanlarda veya yakınında istihdam olanaklarını artırarak banliyö nüfusunu arttırabilir. İkincisi, daha iyi ulaşım altyapısı ve olanakları, kentsel nüfusun daha düşük gayrimenkul maliyetleri ve daha yüksek bir yaşam kalitesi algısı ile banliyö bölgelerine taşınmasına imkan tanır. Üçüncüsü, uygun ulaşım altyapısı ve olanakları ayrıca banliyö ve kırsal kesimdeki nüfusu istihdam firsatları ve kentsel olanaklar için kentsel alanlara seyahat etmeye teşvik edebilir.

\section{Veriler ve Yöntem}

Bu çalışma, Türkiye'nin 1950-2019 yılları arasında demiryolu taşımacılığı, demiryolu altyapısı, nüfus yoğunluğu ve kentleşme arasındaki dinamik bağlantılılık ilişkilerini sorgulamayı amaçlamaktadır. Demiryolu taşımacılı̆̆ için iki ayrı değişken kullanılmıştır. Demiryolu yük taşımacılığı milyon ton km (DYÜT) ve demiryolu yolcu taşımacıllı̆ı milyon yolcu km (DYOT) için veriler TCDD'den alınmıştır. Demiryolu altyapısı içinse değişken olarak toplam demiryolu hat uzunluğu km kullanılmış, verileri ise yine TCDD'den elde edilmiştir. Demografik etkilerin ölçüleceği nüfus yoğunluğu (NYOĞ) değişkeni için $\mathrm{km}^{2}$ başına düşen kişi sayısı verileri ise Birleşmiş Milletler Nüfus Dairesi'nden temin edilmiş̧ir. Diğer demografik değişken olarak kentleşme (KENT) için kent nüfusunun toplam nüfus içerisindeki yüzdelik payı olarak veriler Dünya Bankası'ndan alınmıştır. Kullanılan tüm veriler frekans olarak yıllık olup, Tablo 1 bu çalışmada kullanılan değişkenleri, birimlerini ve tanımlayıcı istatistiklerini göstermektedir. Şekil 5 'te ise verilerin birbirleriyle olan ilişkileri gösterilmektedir.

Tablo 1. Tanımlayıcı İstatistikler

\begin{tabular}{lrrrr}
\hline Değişken & Ortalama & Medyan & Minimum & Maksimum \\
\hline DUZN $(\mathrm{km})$ & 9920.73 & 10277.50 & 7667.00 & 12803.00 \\
DYOT (milyon yolcu km) & 5598.86 & 5556.98 & 2515.51 & 14259.11 \\
DYÜT (milyon ton km) & 7605.28 & 7482.50 & 3078.27 & 14706.56 \\
KENT (\%) & 54.84 & 58.55 & 31.52 & 75.63 \\
NYOĞ $\left(\mathrm{km}^{2}\right.$ başına düşen kişi sayısı) & 64.12 & 63.18 & 27.82 & 108.40 \\
\hline
\end{tabular}

DUZN: Demiryolu hat uzunluğu; DYOT: Demiryolu yolcu taşımacılı̆̆ı; DYÜT: Demiryolu yük taşımacılığı; KENT: Kentleşme; NYOĞ: Nüfus yoğunluğu.

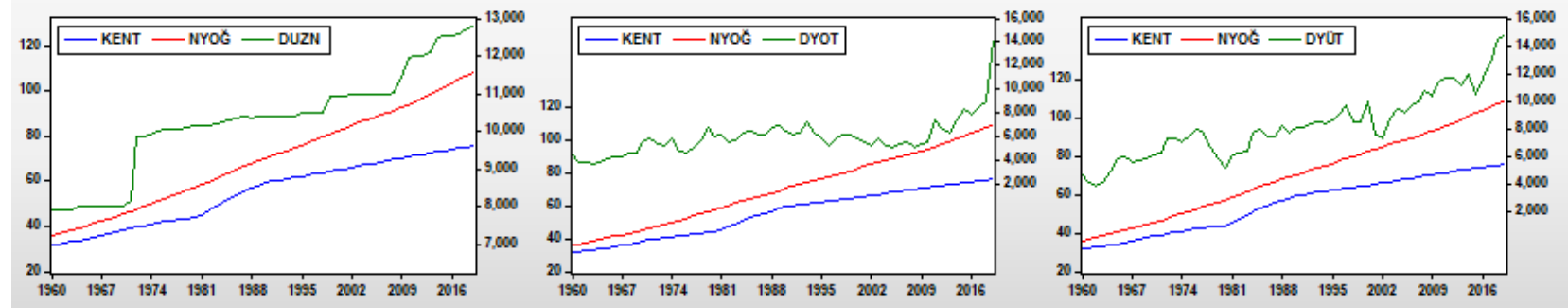

Şekil 5. Demiryolu Taşımacılığı ve Altyapısı ile Kentleşme ve Nüfus Yoğunluğu

Bu çalışmada kullanılan zamanla değiş̧en vektör otoregresif (TVP-VAR) dinamik bağlantılllık yaklaşımı, Diebold ve Yılmaz (2009 ve 2012) yaklaşımlarının geliştirilmiş versiyonu olarak Antonakakis vd. (2020) tarafindan kavramsallaştırılan metodolojiyi takip etmektedir.

$$
\begin{array}{ll}
Y_{t}=\beta_{t} Y_{t-1}+\varepsilon_{t} & \varepsilon_{t} \sim N\left(0, S_{t}\right) \\
\beta_{t}=\beta_{t-1}+v_{t} & v_{t} \sim N\left(0, R_{t}\right)
\end{array}
$$


$Y_{t}=A_{t} \varepsilon_{t-1}+\varepsilon_{t}$

$Y_{t}, \varepsilon_{t}$ ve $v_{t} N \times 1$ vektörler iken; $A_{t}, S_{t}, \beta_{t}$, ve $R_{t}$ are $N \times N$ matrislerdir.

$\tilde{\varphi}_{i j, t}^{g}(h)=\frac{\sum_{t=1}^{h-1} \psi_{i j, t}^{2, g}}{\sum_{i=1}^{N} \sum_{t=1}^{h-1} \psi_{i j, t}^{2, g}}$

$\tilde{\varphi}_{i j, t}^{g}(h)$ h-adım ileri genelleştirilmiş tahmin hatası varyans ayrıştırmalarını (generalized forecast error variance decompositions - GFEVD) belirtir , $\psi_{i j, t}^{g}(h)=S_{i j, t}^{-\frac{1}{2}} A_{h, t} \sum_{t} \varepsilon_{i j, t}, \quad \Sigma_{t}$ hata için kovaryans matrisi $\varepsilon_{i j, t}$ ve $\sum_{j=1}^{N} \tilde{\varphi}_{i j, t}^{g}(h)=1, \sum_{i, j=1}^{N} \widetilde{\varphi}_{i j, t}^{N}(h)=N$.

GFEVD'ye dayalı Toplam Bağlantılılık Endeksi (TBE) aşağıdaki şekilde formüle edilebilir.

$T B E_{t}^{g}(h)=\frac{\sum_{i, j=1, i \neq j}^{N} \widetilde{\varphi}_{i j, t}^{g}(h)}{\sum_{j=1}^{N} \widetilde{\varphi}_{i j, t}^{g}(h)} \times 100$

Her bir değişkenin üzerindeki şokları diğer tüm değişkenlere iletimi (i'den j'lere) yani Toplam Aktarılan Bağlantılılık (TAB) aşağıdaki şekilde formüle edilebilir.

$T A B_{i \rightarrow j, t}^{g}(h)=\frac{\sum_{j=1, i \neq j}^{N} \widetilde{\varphi}_{j i, t}^{g}(h)}{\sum_{j=1}^{N} \widetilde{\varphi}_{j i, t}^{g}(h)} \times 100$

Her bir değişkene diğer tüm değişkenlerdeki şokların iletimi (j’lerden i’ye) yani Toplam Gelen Bağlantılılık (TGB) aşağıdaki gibi formüle edilebilir.

$T G B_{i \leftarrow j, t}^{g}(h)=\frac{\sum_{j=1, i \neq j}^{N} \widetilde{\varphi}_{i j, t}^{g}(h)}{\sum_{i=1}^{N} \widetilde{\varphi}_{i j, t}^{g}(h)} \times 100$

Toplam aktarılan ve toplam gelen bağlantılılık parametreleri arasındaki farkı yani Net Toplam Bağlantılılık (NET) şu şekilde formüle edilebilir.

$N E T_{i, t}^{g}(h)=T A B_{i \rightarrow j, t}^{g}(h)-T G B_{i-j, t}^{g}(h)$

Net toplam bağlantılılığın işareti eğer; (i) sıfırdan büyük oluşu $\left(C_{i, t}^{g}(h)>0\right)$ değişskenin diğer değişkenlerden aldığı şoklardan daha fazla üzerindeki şokları diğer değişkenlere aktarabildiğini gösterir, (ii) sıfırdan küçük oluşu ise $\left(C_{i, t}^{g}(h)<0\right)$ değişkenin kendi üzerindeki şokları diğer değişkenlere ilettiğinden daha fazla diğer değişkenlerdeki şokları kendi üzerine aldığını göstermektedir.

Son olarak, değişkenler arasındaki ikili bağlantılılığ incelemek için Toplam Yönsel Bağlantıllı̆ı̆g şu şekilde formüle edebiliriz.

$T Y B_{i j}(h)=\frac{\widetilde{\varphi}_{j i, t}^{g}(h)-\widetilde{\varphi}_{i j, t}^{g}(h)}{N} \times 100$

Demiryolu taşımacılığı ve altyapısının demografik etkilerini incelerken kullanılacak olan parametrelerin tamamı yukarıda verilmiştir. Bu parametrelerin tarihsel süreçte birer zaman serisi olarak türetilecek ve incelenebilecek olması analizlerin dinamik kısmını oluşturmaktadır.

\section{Bulgular}


Dinamik bağlantılılık analizlerine geçmeden önce, değişkenlerin durağanlık özelliklerini kontrol etmek gerekmektedir. Bu kapsamda Elliott vd. (1996) tarafindan geliştirilen Dickey-Fuller genelleştirilmiş en küçük kareler (DF-GLS) birim kök testi uygulanmıştır. Birim kök test sonuçları Tablo 2'de sunulmuştur.

Tablo 2. Birim Kök Test Sonuçları

\begin{tabular}{lrr}
\hline Değişken & t-stat (düzey) & t-stat (birinci fark) \\
\hline DUZN & -2.137 & $-7.548^{* * *}$ \\
DYOT & -1.798 & $-6.467^{* * *}$ \\
DYÜT & -2.804 & $-7.845^{* * *}$ \\
KENT & -1.195 & $-6.924^{* * *}$ \\
NYOĞ & -1.441 & $-6.759^{* * *}$ \\
\hline
\end{tabular}

Not: Test logaritmik serilere uygulanmıştır. Testin sıfır hipotezi, serinin birim kök içerdiği yani durağan olmadığı şeklindedir. *** yüzde 1 anlamlılık düzeyinde serinin sıfır hipotezinin reddedildiğini gösterir. DF-GLS için kritik değerler Elliott vd. (1996)'dan alınmıştır.

DF-GLS birim kök test sonuçlarına göre çalışmada kullanılan tüm değişkenlerin seviyede durağan değil ancak ilk farkta durağan oldukları tespit edilmiştir. Bu nedenle, bağlantılılık analizleri için gerekli şartları sağlaması bakımından tüm değişkenlerin logaritmik fark serilerinin kullanılması uygundur. Buradan hareketle, demiryolu taşımacılığı ve altyapısı ile kentleşme arasındaki bağlantılılık parametreleri Tablo 3, nüfus yoğunluğu ile arasındaki bağlantılılık parametreleri ise Tablo 4'te verilmiştir. İlk olarak genel sonuçlar göz önüne alındığında, Toplam Bağlantılılık Endeksi (TBE)'nin demiryolu taşımacılığı ve altyapısı ile kentleşme arasında yüzde 70.22 , nüfus yoğunluğu ile ise yüzde 71.35 seviyelerinde olduğu görülmektedir. Bu sonuçlara göre demiryolu taşımacıllğı ve altyapısı ile kentleşme ve nüfus yoğunluğu arasında ortalamanın üzerinde seyreden bir bağlantılılık olduğu görülmektedir.

Tablo 3. Bağlantılılık Parametreleri (Kentleşme ve Demiryolları)

\begin{tabular}{lrrrrr}
\hline & DUZN & DYOT & DYÜT & KENT & TGB \\
\hline DUZN & 26.75 & 20.34 & 24.91 & 28.01 & 73.25 \\
DYOT & 23.20 & 29.09 & 23.78 & 23.93 & 70.91 \\
DYÜT & 24.95 & 16.95 & 30.53 & 27.58 & 69.47 \\
KENT & 25.88 & 14.78 & 26.60 & 32.74 & 67.26 \\
\hline TAB & 74.02 & 52.07 & 75.29 & 79.52 & 280.90 \\
\hline NET & 0.77 & -18.84 & 5.81 & 12.26 & \\
\hline
\end{tabular}

$\mathrm{TBE}=\mathbf{7 0 . 2 2}$

Not: DUZN: Demiryolu hat uzunluğu; DYOT: Demiryolu yolcu taşımacılığı; DYÜT: Demiryolu yük taşımacılığı; KENT: Kentleşme; TBE: Toplam Bağlantılılık Endeksi; TAB: Toplam Aktarılan Bağlantılılık; TGB: Toplam Gelen Bağlantılılık; NET: Net Toplam Bağlantılılık (NET=TAB - TGB).

Kentleşme ile demiryolu taşımacılığı ve altyapısını incelediğimiz Tablo 3'te ilk olarak dikkati çeken NET satırındaki rakamlar olmuştur. Burada (-18.84) gibi yüksek bir oranla demiryolu yolcu taşımacılığının alıcı diğer tüm değişkenlerin ise aktarıcı olduğu görülmektedir. Kentleşmenin (12.26) ile gayet net ve en yüksek düzeyde aktarıcı olması önemli bir sonuçtur. Yük taşımacılığı (5.81) ve demiryolu hat uzunluğu ise (0.77) ile nispeten daha düşük seviyelerde aktarıcı rolüne sahiptirler. Değişkenler arasındaki ikili bağlantıllılık analizleri için tabloda sütundan satıra doğru okuma yapılmaktadır. KENT satırı demiryollarından kentleşmeye, KENT sütunu ise kentleşmeden demiryollarına olan etkileşimi göstermektedir. Demiryollarından kentleşmeye doğru sirasıyla (26.60) ile demiryolu yük taşımacılığından, (25.88) ile demiryolu hat uzunluğundan ve (14.78) ile demiryolu yolcu taşımacıllı̆ı̆ından aktarım 
gelmektedir. Kentleşmeden demiryollarına doğru ise sırasıyla (28.01) ile demiryolu hat uzunluğuna, (27.58) ile demiryolu yük taşımacılığına ve (23.93) ile demiryolu yolcu taşımacılığına aktarım gitmektedir. Bu rakamlar karşılaştırıldığında ise net bir şekilde kentleşmeden demiryollarına aktarımın olduğu görülmektedir. Burada kentleşmeden sırasıyla (9.15) ile demiryolu yolcu taşımacılığına, (2.13) ile demiryolu hat uzunluğuna ve son olarak (0.98) ile demiryolu yük taşımacılığına aktarım olduğu tespit edilmiştir.

KENT - DUZN

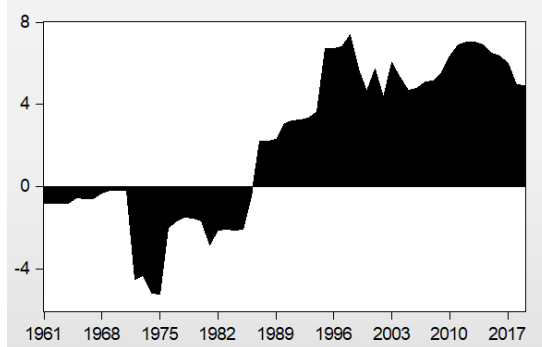

KENT - DYOT

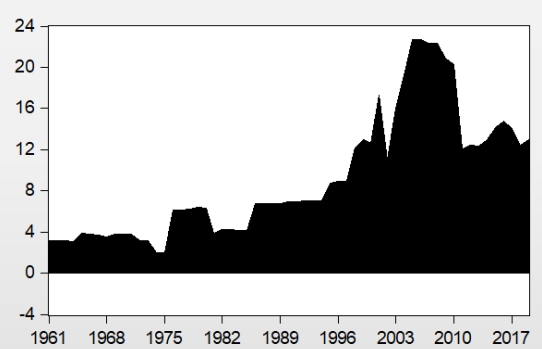

KENT - DYÜT

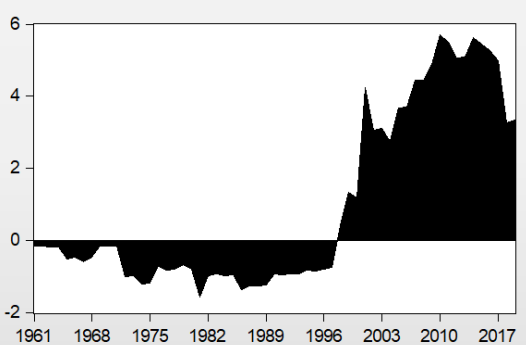

Şekil 6. İkili Bağlantılılık (Kentleşme ve Demiryolları)

Tablo 3'deki rakamların tarihsel süreç içerisindeki değiş̧imleri ise Şekil 6'da görülmektedir. Kentleşme ile demiryolu hat uzunluğu arasındaki bağlantıllılı incelendiğinde $1980^{\prime}$ lerin ortalarına kadar kentleşmeye aktarım sonrasında ise kentleşmeden aktarım olduğu görülmektedir. Benzer bir rol değişimi kentleşme ile demiryolu yük taşımacıllğı arasında 1990'ların sonlarında yaşanmıştır. Kentleşme ile demiryolu yolcu taşımacıllı̆ı arasında ise tüm süreç boyunca aktarıcı olan bir kentleşme profili olduğu görülmektedir.

Nüfus yoğunluğu ile demiryolu taşımacıllı̆̆ ve altyapısını incelediğimiz Tablo 4'teki NET satırına göre (-18.75) gibi yüksek bir oranla yine demiryolu yolcu taşımacılığının alıcı diğer tüm değişkenlerin ise aktarıcı olduğu görülmektedir. Nüfus yoğunluğunun (11.63) ile yine gayet net ve en yüksek düzeyde aktarıcı oluyor olması önemli ve kentleşme ile tutarlı bir sonuçtur. Yük taşımacılığı (5.81) ve demiryolu hat uzunluğu ise (2.53) ile nispeten daha düşük seviyelerde aktarıcı rolüne sahiptirler. Burada kentleşme analizlerine nazaran, demiryolu hat uzunluğunun net aktarıcı rolü daha yüksek bir oranla gerçekleşmiştir.

Tablo 4. Bağlantılılık Parametreleri (Nüfus Yoğunluğu ve Demiryolları)

\begin{tabular}{lrrrrr}
\hline & DUZN & DYOT & DYÜT & NYOĞ & TGB \\
\hline DUZN & 28.14 & 17.74 & 25.19 & 28.94 & 71.86 \\
DYOT & 23.48 & 27.82 & 24.65 & 24.05 & 72.18 \\
DYÜT & 24.68 & 19.05 & 28.14 & 28.13 & 71.86 \\
NYOĞ & 26.23 & 16.65 & 26.61 & 30.51 & 69.49 \\
\hline TAB & 74.39 & 53.43 & 76.45 & 81.11 & 285.39 \\
\hline NET & 2.53 & -18.75 & 4.59 & 11.63 & \\
\hline
\end{tabular}

$\mathrm{TBE}=71.35$

Not: DUZN: Demiryolu hat uzunluğu; DYOT: Demiryolu yolcu taşımacılığı; DYÜT: Demiryolu yük taşımacılığı; NYOĞ: Nüfus yoğunluğu; TBE: Toplam Bağlantılılık Endeksi; TAB: Toplam Aktarılan Bağlantılılık; TGB: Toplam Gelen Bağlantılılık; NET: Net Toplam Bağlantılılık (NET=TAB - TGB).

Nüfus yoğunluğu ile demiryolları arasındaki ikili bağlantılılık analizleri için yine tabloda sütundan satıra doğru okuma yapılmaktadır. NYOĞ satırı demiryollarından nüfus yoğunluğuna, NYOĞ sütunu ise nüfus yoğunluğundan demiryollarına olan yönelmeyi göstermektedir. Demiryollarından nüfus yoğunluğuna doğru sırasıyla (26.61) ile demiryolu yük taşımacılığından, (26.23) ile demiryolu hat uzunluğundan ve (16.65) ile demiryolu yolcu 
taşımacılığından aktarım gelmektedir. Nüfus yoğunluğundan demiryollarına doğru ise sırasıyla (28.94) ile demiryolu hat uzunluğuna, (28.13) ile demiryolu yük taşımacilığına ve (24.05) ile demiryolu yolcu taşımacilığına aktarım gitmektedir. Kentleşme analizleriyle sıralama anlamında tutarlı olan bu rakamlar karşılaştırıldığında ise net bir şekilde nüfus yoğunluğundan demiryollarına aktarımın olduğu görülmektedir. Burada nüfus yoğunluğundan sırasıyla (7.4) ile demiryolu yolcu taşımacılığına, (2.71) ile demiryolu hat uzunluğuna ve son olarak (1.52) ile demiryolu yük taşımacılığına aktarım olduğu tespit edilmiştir.

NYOĞ - DUZN

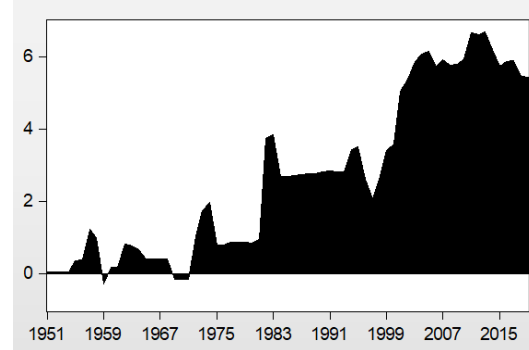

NYOG - DYOT



NYOG - DYÜT

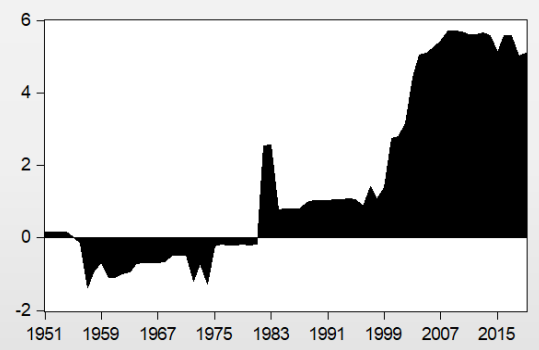

Şekil 7. İkili Bağlantılılık (Nüfus Yoğunluğu ve Demiryolları)

Tarihsel süreç içerisindeki ikili bağlantılılık parametrelerinde yaşanan değişimler ise Şekil 7'de görülmektedir. Kentleşme ile demiryolu hat uzunluğu arasındaki bağlantılılık incelendiğinde 1960'ların ve 1970'lerin başlarında kısa bir süre nüfus yoğunluğuna aktarım olduğu görülmektedir, sürecin geri kalanında tamamen nüfus yoğunluğunun aktarıcı olduğu görülmektedir. Nüfus yoğunluğu ile demiryolu yolcu taşımacıllğı arasında ise tüm sürę̧ boyunca aktarıcı olan bir demografi profili olduğu görülmektedir. Nüfus yoğunluğu ile demiryolu yük taşımacıllı̆ı arasındaki bağlantılllık incelendiğinde ise 1950'lerin ortalarından 1980'lerin başına kadar olan süreçte demiryolu yük taşımacıllı̆ı aktarıcı iken diğer tüm dönem zarfında nüfus yoğunluğu aktarıcı olarak rol oynamıştır.

\section{SONUÇ:}

Coğrafyaların kaderini değiştiren en önemli unsurlar arasında yer alan ulaşım ekonomik, sosyal ve kültürel bir zenginlik unsurudur. İnsanlık tarihine yön veren ulaşım olanakları arasında şiir sanatında bile kendine yer bulabilen demiryollarına ayrı bir bahis açmak gerekir. Elbette kara, hava ve deniz ulaşım modları da toplumsal yapı açısından önem arz etmesine rağmen, bu çalışma ile sadece, demiryollarının demografik etkilerinin Türkiye özelinde incelemesi amaçlanmıştır. Bu kapsamda, 1950-2019 döneminde, demiryolu taşımacılığı ve altyapısının nüfus yoğunluğu ve kentleşme ile arasındaki etkileşim dinamik bağlantılılık yöntemi ile analiz edilmiştir.

Elde edilen bulgulara göre, değiş̧ken gruplarının toplam, değişkenlerin ise net ve ikili bağlantıllılık parametreleri ilginç sonuçlar ortaya koymaktadır. Öncelikle toplam bağlantılılık parametreleri göz önüne alındığında kentleşme ve demiryolları grubunda (70.22), nüfus yoğunluğu ve demiryolları grubunda ise (71.35) oranında ölçülmüştür. Ortalamanın üzerinde olan bu grup parametrelerine göre nüfus yoğunluğu ile demiryolları arasındaki etkileşim ufak da olsa daha yoğun olduğu gözlenmektedir.

Net bağlantılılık parametreleri dikkate alındığında kentleşme ve demiryolları grubunda, kentleşme (11.63), demiryolu yük taşımacılığ 1 (5.81) ve hat uzunluğu $(0.77)$ net aktarıcı, yolcu taşımacılığı $(-18.84)$ ise net alıcı durumundadır. Nüfus yoğunluğu ve demiryolları grubunda ise, nüfus yoğunluğu (12.26), demiryolu yük taşımacıllğı (4.59) ve hat uzunluğu (2.53) net aktarıcı, yolcu taşımacılığı (-18.75) ise net alıcı durumundadır. Demografik etkilerin ölçümlendiği kentleşme ve nüfus yoğunluğu değişkenlerinin en yüksek oranlarla net aktarıcı olmaları, demiryollarının demografik etkilerine nazaran demografik değişkenlerin daha yüksek oranda demiryolları üzerinde etkinlik gösterdiği yönünde bir saptamaya yol açmaktadır. Bir diğer taraftan, her iki grupta da aynı sıralama ve doğrultuda bağlantılılık parametreleri olduğu demiryolları ile demografi arasında tutarlı bir etkileşimin varlığını kanıtlamaktadır.

İkili bağlantılılık parametreleri incelendiği zaman hem kentleşme ve demiryolları grubunda hem de nüfus yoğunluğu ve demiryolları grubunda benzer bir senaryo olduğu saptanmıştır. Parametre ortalamalarının her iki grupta da karşılıklı etkileşimin yoğun ve yakın aralıkta seyretmekte olduğunu göstermesi de önemlidir. Kentleşmeden sırasıyla 
demiryolu yolcu taşımacıllğg $(9.15)$, demiryolu hat uzunluğu (2.13) ve demiryolu yük taşımacıllğı (0.98) yönünde aktarım olduğu görülmüştür. Nüfus yoğunluğundan da aynı sırayla demiryolu yolcu taşımacılığı (7.4), demiryolu hat uzunluğu (2.71) ve demiryolu yük taşımacılığı (1.52) değişkenlerine aktarım olduğu görülmüştür. Demografi değişkenlerinin bu denli etkinlik göstermelerini yorumlamak gerekirse, nüfusun ihtiyaçları doğrultusunda demiryolu yolcu taşımacılığı nispeten öncül konum ve seviyede etkilenmekte, ardından demiryolu altyapısının genişletilmesine ihtiyaç duyulmakta, son olarak da demiryolu yük taşımacılığının düşük de olsa alıcı rol oynadığı görülmektedir.

Çalışmaya konu olan 1950-2019 dönemi incelendiğinde, demiryolu altyapı ağının genişlemesinin belirli dönemlerde yatay seyretmesi, karayolu taşımacılığı karşısında geri planda kalması ve giderek etkinliği kaybetmeye başlamasıyla, belki de demiryolları dışında kalan kara, hava ve deniz ulaşım modlarının da nüfus üzerinde etkili olmuş olabileceği dikkate alınabilir. Ancak burada unutulmaması gereken bazı hususlar mevcuttur, bunların başında demiryollarının etkisiz olarak görülmemesi ve diğer ulaşım modlarına görece sahip olduğu avantajları olduğu gerçeğidir. Demiryollarının taşıma kapasitesi, ulaşım maliyetleri ve diğer modlara bağlantıları sağlandığında etkinliğinin en üst seviyelere ulaşabilme avantajları da göz önüne alınması gerekmektedir. Böylece hem bölgesel hem de ulusal düzey ekonomilerini olumlu etkileme potansiyeli oluşabilmektedir.

Demiryollarının demografik etkileri, demografinin demiryollarına etkileri ile iç içe geçmiş bir süreç içerisinde ilerlemektedir. Ulaşım altyapıları, azalmayan ve daima artan nüfuslar tarafından yürütülen ekonomik faaliyetlerin sürdürülebilirliği için önemli gereksinimler arasındadır. Böylece taşımacılık faaliyetleri için de uygun bir zemin temin edilmiş olmaktadır. Ekonomik faaliyetlerin aktörleri olarak firmaların ve hanehalklarının erişilebilirliği, altyapı politikaları ve ulaşım hareketliliği bir bütün olarak ulaşımdaki talebin gerçekleşmesinde önemli rol oynamaktadır. Bu bağlamda, demiryollarının etkinliğini bölgesel ve dönemsel faktörler doğrultusunda incelemek gerekirse, sektörel etkilerin değerlendirilmesi önemlidir. Kent ve kırsal alanlar arasındaki istihdam, üretim, sanayi ve tarımsal ekonomik faaliyetlerin dağlımı bakımından demiryolu altyapısının getirdiği erişilebilirlik değer arz etmektedir.

Analiz edilen süreçte kentleşme yüzde 30'lardan yüzde 75 seviyelerine, nüfus yoğunluğu ise 27 'den 108 seviyelerine artarken, ülkenin demografik yapısı kentsel alanlara doğru kaymaya devam etse de Türkiye'nin kırsal alanlarında yoksulluğu azaltma hedeflerine ulaşmak için kırsal ekonomiye yatırım yapmaya devam etmek önemli olacaktır. Kırsal alanlar ve kentsel yığılmalar arasındaki yoğun bağlantıları tanımlayan gelişmiş ulaşım altyapısı ve kentleşmenin artmasıyla sağlanan bağlantılar, kırsal kesimlerin işgücü piyasalarına erişimlerinin yanı sıra kırsal kesimlerin ürün pazarlarına erişimlerinin de artmasını kolaylaştırmaktadır.

Ulaşım politikaları ve yatırımları bakımından, demiryolu ağının genişletilmesi ve modernize edilmesi ne kadar önemli ise, diğer ulaşım modlarına entegre edilmesi de en az o seviyede önem arz etmektedir. Kentlerin ve kırsal kesimlerin piyasa dengesi açısından konumları ve oynadıkları rolü değiştirebilme potansiyeline sahip ulaşım modları arasında yer alan demiryolu taşımacılığı açısından da bu entegrasyon önemlidir. Kent ile kırsal kesim arasında sıcak ilişkilere konu olan tarım, sanayi ve turizm gibi sektörel yapılanmalar açısından da demiryollarının besleyici rolü politika yapıcılar açısından dikkate alınmalıdır. Ayrıca, çalışmada kullanılan yöntem sayesinde, politika yapıcılar için demiryolu taşımacılığı ve altyapısı özelinde daha fazla ampirik destek sağlanması amaçlanmaktadır. Bu desteğin en yoğun olarak görüldüğü hususların başında, analize konu olan dönemi bir süreç olarak dinamik bir şekilde izlemeye imkan sağlaması yer almaktadır.

Çalışmanın literatüre olan katkıları her ne seviyede olursa olsun, belirli kısıtlar altında olduğunun görülmesi ve gelecek çalışmalara yol gösterici olması mutlak literatür katkısı olarak değerlendirilmelidir. Başlangıç olarak, bu çalışmanın demiryolu altyapısı ve taşımacılığı bağlamında olduğu göz önünde tutulmalıdır. Ulaşım ekonomisi alanında her daim farklı verilere, özellikle de yüksek frekans ve geniş coğrafi boyutları olanlara ihtiyaç duyulmaktadır. Bunun yanı sıra, veri tutarlılığı bağlamında, çeşitli ülkeler arasındaki ulaşım modları birim, zaman boyutu ve ölçülerine göre farklılık gösterebilmektedir. Bu nedenle, gelecekteki araştırmalar, farklı ülke veya ülke gruplarını, bölgesel veya ulusal düzeyleri, zaman boyutlarını ve değişkenleri analizlere dahil etmek suretiyle hem ulaşım ve demografi arasındaki hem de dolaylı etkilerini incelemelerine dahil etmeleri teşvik edilmektedir.

\section{Etik Standart ile Uyumluluk}

Çıkar Çatışması: Yazar herhangi bir çıkar çatışmasının olmadı̆̆ını beyan eder. 
Etik Kurul İzni: Bu çalışma için etik kurul iznine gerek yoktur.

Finansal Destek: Bulunmamaktadır.

Teșekkür: Bulunmamaktadır.

\section{KAYNAKÇA:}

\section{Kitaplar:}

Abdülhamid, S. (1999). Siyasi Hatıratım. Dergah Yayınları.

Allen, K., \& MaClennan, M.C. (1970). Regional Problems and Policies in Italy and France. Sage.

Earl, E.M. (1966). Turkey, The Great Powers and The Bagdad Railway, A study in Imperialism. Russell and Russell.

Eldem, V. (1970). Osmanlı İmparatorluğunun İktisadi Şartları Hakkında Bir Tetkik. İş Bankası Yayınları.

Faroqui, S., McGowan, B., Quataert, D., \& Pamuk, S. (1997). Economic and Social History of the Ottoman Empire Vol 2: 1600-1914. Cambridge University Press.

Talbot, E. (1981). Steam in Turkey. Continental Railways Circle.

William, G.A. (1958). Economic effects of Camp Creek Road improvement. College Station: Texas A and M University and Texas Transportation Institute.

Makaleler:

Antonakakis, N., Chatziantoniou, I., \& Gabauer, D. (2020). Refined measures of dynamic connectedness based on time-varying parameter vector autoregressions. Journal of Risk and Financial Management, 13(4): 84.

Aschauer, D.A. (1989). Is public expenditure productive? Journal of Monetary Economics, 23: 177-200.

Atack, J., Bateman, F., Haines, M., \& Margo, R.A. (2009). Did Railroads Induce or Follow Economic Growth? Urbanization and Population Growth in the American Midwest, 1850-60. NBER Working Paper, 14640.

Briggs, R. (1981). The interstate highway system and development in nonmetropolitan areas. Transportation Research Record, 812: 9-12.

Boarnet, M.G., \& Haughwout, A. (2000). Do highways matter? Evidence and policy implications of highways' influence on metropolitan development. Urban and Regional Planning and Economics, 5(3): 24-50.

Bohm, R.A. \& Patterson, D.A. (1971). Interstate highways and the growth and distribution of population. American Statistical Association, 4(6): 56-71.

Bougheas, S., Demetriades, P.O., Theofanis, P., \& Mamuneas, T.P. (2000). Infrastructure, Specialization, and Economic Growth. The Canadian Journal of Economics, 33(2): 506-522.

Carlino, G.A., \& Mills, E.S. (1987). The Determinants of County Growth. Journal of Regional Science, 27(1): 3954.

Cervero, R., \& Hansen, M. (2002). Induced travel demand and induced road investment: A simultaneousequation analysis. Journal of Transport Economics and Policy, 36(3): 469-490.

Chi, G. (2010). The Impacts of Highway Expansion on Population Change: An Integrated Spatial Approach. Rural Sociology, 75(1): 58-89.

Chi, G., Voss, P.R., \& Deller, S.C. (2006). Rethinking highway effects on population. Public Works Management and Policy, 11(1): 18-32. 
Crane, L.M., \& Leatham, D.J. (1990). The distributed lag between transportation expenditures and rural income and employment. American Agricultural Economics Association, 3(6): 345-376.

Diebold, F. X., \& Y1lmaz, K. (2009). Measuring financial asset return and volatility spillovers, with application to global equity markets. The Economic Journal, 119(534): 158-171.

Diebold, F.X., \& Yilmaz, K. (2012). Better to give than to receive: Predictive directional measurement of volatility spillovers. International Journal of Forecasting, 28(1): 57-66.

Doeksen, G.A. (1990). The role of extension concerning infrastructure issues in the 90s. American Agricultural Economics Association, 4(2): 213-237.

Elliott, G., Rothenberg, T.J., \& Stock, J.H. (1996). Efficient tests for an autoregressive unit root. Econometrica, 64(4): 813-836.

Eyerly, R.W., Twark, R.W., \& Downing, R.H. (1987). Interstate highway system: Reshaping the non-urban areas of Pennsylvania. Transportation Research Record, 1125: 1-14.

Fuguitt, G.V., \& Beale, C.L. (1976). Population changes in nonmetropolitan cities and towns. Agricultural Economic Research Service, 6(2), 42-64.

Fuguitt, G.V., \& Brown, D. (1990). Residential preferences and population redistribution. Demography, 27(4): 589-600.

Gaegler, A.M., James, W.M., \& Weiner, P. (1979). Dynamic Social and Economic Effects of the Connecticut Turnpike. Transportation Research Record, 716: 28-32.

Gamble, H.B., Raphael, D.L., \& Sauerlender, D.H. (1966). Direct and indirect economic impacts of highway interchange development. Highway Research Record, 149: 42-55.

Gerardin, B. (1991). Investment in transport infrastructure and regional development. Infrastructure and Regional Development, 4(1): 52-60.

Gramlich, E.M. (1994). Infrastructure Investment: A Review Essay. Journal of Economic Literature, 32: 11761196.

Hilewick, C.L., Deak, E., \& Heinze, E. (1980). A Simulation of Communications and Transportation Investments. Growth and Change, (11)3: 26-38.

Hobbs, D.J., \& Campbell, R.R. (1967). Traffic flow and population change. Business and Government Review, 8(3): 5-11.

Humphrey, C.R. (1980). The promotion of growth in small urban places and its impact on population change. Social Science Quarterly, 61: 581-594.

Kanwit, E.L., \& Todd, T.R. (1961). Recent population trends and their highway implications. Highway Research Board Proceedings, 40: 1-34.

Lakshmanan, T.R. (2007). The Wider Economic Benefits of Transportation: An Overview. OECD International Transport Forum, Joint Transportation Research Centre Discussion Paper, 8(12).

Levinson, D. (2008). Density and dispersion: the co-development of land use and rail in London. Journal of Economic Geography, 8: 55-77.

Lichter, D.T., \& Fuguitt, G.V. (1980). Demographic response to transportation innovation: The case of the interstate highway. Social Forces, 59(2): 492-512.

McHugh, R.J., \& Wilkinson, J.T. (1988). A Random Effects Approach to Substate Growth Models: A Comment on the Determinants of County Growth. Journal of Regional Science, 28(2): 271-273.

Moon, H.E. (1988). Interstate highway interchanges as instigators of nonmetropolitan development. Transportation Research Record, 1125: 8-14. 
Munnell, A.H. (1990). Why Has Productivity Declined? Productivity and Public Investment. New England Economic Review, 1: 3-22.

Robinson Jr., G.R., \& Kapo, K.E. (2004). A GIS analysis of suitability for construction aggregate recycling sites using Regional transportation network and population density features. Resources, Conservation and Recycling, 42: 351-365.

Schafer, V., \& Victor, D.G. (2000). The future mobility of the world population. Transportation Research Part A, 34:171-205.

Snow, N.B. (2010). Changes in Transportation Infrastructure and Commuting Patterns in U.S. Metropolitan Areas, 1960-2000. American Economic Association, 345: 32-58.

Taaffe, E.J., Morrill, R.L., \& Gould, P.R. (1963). Transport Expansion in Underdeveloped Countries: A Comparative Analysis. Geographical Review, 53(4): 503-529.

Thiel, F.I. (1962). Social effects of modern highway transportation. Highway Research Board Bulletin, 327: 1-20.

Voss, P.R., \& Chi, G. (2006). Highways and population change. Rural Sociology, 71(1): 33-58.

Zahavi, Y. (1976). The effects of Transportation Systems on the Spatial Distributions of Population and Jobs. Operations Research Society and The Institute of Management Science, 3(5): 197-216.

Zhou, J., Yang, L., Xu, Y., \& Liu, C. (2007). The economic performance of transportation infrastructure: an empirical study on the recent development of China. World Transactions on Engineering and Technology Education UICEE, 6(1): 193-197.

Tezler:

Üstün, S. (1997). Turkey and the Marshall Plan: Strive for Aid [Master's Thesis, University College London].

Wang, K.S. (1987). A longitudinal examination of the effect of the interstate highway system on the economic and demographic growth within nonmetropolitan counties in the state of Georgia, 1960-1980 [Doctoral Thesis, University of Georgia].

Wisenbaker, V.B. (1973). The effects of the interstate highway system on the population of nonmetropolitan counties in the South [Doctoral Thesis, University of Georgia].

Web Siteleri:

Url 1: https://www.tcdd.gov.tr/kurumsal/istatistikler, Erişim Tarihi: 16.07.2021.

Url 2: https://static.tcdd.gov.tr/webfiles/userfiles/images/tcdd-demiryolu-haritasi.jpg, Erişim Tarihi: 24.07.2021. 